\title{
Discovery Learning Effect on Mathemathic Learning
}

\author{
David Okwina \\ Faculty of Education, Uganda Martyrs University, Uganda \\ Received: August 3, 2020 \\ Received in Revised: August 11, 2020 \\ Accepted: August 13, 2020
}

\begin{abstract}
This study aimed to improve the mathematics learning through the application of the Discovery Learning model with a scientific approach. The application of the Discovery Learning learning model with an effective scientific approach can increase the frequency of activeness and activities in the teaching and learning process according to the observations of student attitudes during the implementation of classroom action research. It showed that Student learning outcomes that are not entirely satisfactory are also caused by several factors, namely individual student factors, student environment and school environment.
\end{abstract}

Keywords: Discovery Learning Model, Scientific Approach, Mathemathic Learning

\section{Introduction}

Every nation and state makes various efforts and efforts to prepare quality human resources in order to win the competition in this era of globalization. Education is one of the tools to create a quality society. Therefore, the Indonesian government is always trying to improve the quality of education, even though the results have not met expectations.

Education has an important role in the development of students so that the goals of national education can be achieved, this is in accordance with the Law on the Ministry of National Education N0. 20 of 2003 Chapter II Article 3, which reads "National Education has the function of developing abilities and shaping a dignified character and civilization in the framework of educating the nation's life, aiming at developing the potential of students to become human beings who believe and devote to God Almighty, have noble character, healthy, knowledgeable, capable, creative, independent and a democratic and responsible citizen.

Teaching and learning in schools is a series of consciously planned activities (Wells, 1993; Hirst, 2010; Moore, 1986; Mercer \& Fisher, 1992). With good planning will support the success of teaching, which in turn will also improve the quality of education. One of the efforts to improve human resources is through the learning process in schools which is implemented in all subjects, one of which is Mathematics.

Mathematics is a subject that requires understanding. That is, in studying Mathematics, understanding is needed, namely the ability to carry out activities and the teaching and learning process or to understand the assignments given by the teaching staff because Mathematics is abstract, so there is a need for a way to manage the teaching and learning process so that Mathematics is easily digested by students properly and is more meaningful and benefit their life. Therefore, a teacher must be very clever in choosing teaching methods in the learning process so that it can improve learning outcomes

Based on the results of observations by researchers shows that in the class there are heterogeneous students, the situation of students in the class varies greatly, some are indeed smart and master 
Mathematics, some are moderate or mediocre, and there are also those who really don't like it and are really not happy and have little interest in learning. In the learning process, there are still students who have difficulty understanding the material taught by the teacher, difficulty working on the questions given, lack of interest in receiving lessons, and students are less active in the teaching and learning process. This is due to the lack of student attention in participating in the learning process, lack of communication between students and teachers, and lack of student motivation to learn. As a result, students are not able to solve the problems faced in solving the given questions, the mastery of concepts and student learning outcomes is still lacking, and learning does not take place as desired.

Based on the description above, the researcher then designs a learning model. Discovery Learning learning model with a scientific approach, is a learning model in which students are required to be more active in solving problems, finding their own solutions and being able to express ideas / ideas in the learning process. With the many interactions between teachers and students it can increase student understanding and it is hoped that it can improve student learning outcomes.

\section{Learning Outcomes Profile}

The teaching and learning process that occurs in the classroom cannot be separated from learning activities for students and teaching activities for teachers. Students who learn from each other have different abilities. Therefore, teaching and learning activities should be developed while paying attention to the level of intellectual development of students.

Based on the results of observations the learning outcomes obtained by students are still lacking. This is evidenced by the fact that there are still many students who score less than the Miniamal Completeness Criteria set by the school, namely 65. Therefore, teaching and learning activities should be developed while paying attention to the intellectual development of students.

Student learning outcomes that are not entirely satisfactory are also caused by several factors, namely individual student factors, student environment and school environment. On the individual student factors, students are somewhat less concerned with the material described by the teacher because their learning awareness is also lacking.

Based on the description above, it appears that student learning outcomes are still lacking. There needs to be an update in terms of the individual students themselves and from the tools proclaimed by the subject teacher so that what is planned can be achieved.

\section{Problem Formulation Based on Learning Process Profile and Learning Outcomes}

Based on the profile of the learning process in the classroom and the learning outcomes that have been stated above, the problem in this classroom action research can be formulated as follows: "Does applying Discovery Learning with a scientific approach can improve the mathematics learning outcomes".

\section{Forms of Action to Solve Problems According to Problems}

To solve the problems that occur described above, the form of action chosen is to apply the Discovery Learning learning method with a scientific approach.

\section{Purpose}

In accordance with the formulation of the problem above, the purpose of this study is "To improve the mathematics learning outcomes through the application of the Discovery Learnign learning model with a scientific approach". 


\section{Learning Model Discovery Learning}

Discovery learning model is a component of educational practice which includes teaching methods that promote active learning, process-oriented, self-directed, self-seeking, and reflective (Mariyana, 2019; Barjesteh, 2019; Gregory, 2006; Brooks \& Madden 2011)

According to Suwangsih and Tiurlina, discovery learning model is a teaching method / model that regulates teaching in such a way that children acquire knowledge that they do not previously know through notification; partially or completely found by themselves.

In addition, according to Bruner in Winataputra, meaningful learning can only occur through discovery learning. In order for learning to be meaningful and have a strong information structure, students must actively identify the key principles they have discovered on their own, not just accept explanations from the teacher.

Bruner believes that discovery learning is a learning process in which teachers must create problematic learning situations, stimulate students with questions, encourage students to seek their own answers, and conduct experiments. Another form of discovery learning is the teacher. presents examples and students work with them until they can find out for themselves the relationships between the concepts.

Klahr \& Nigam (2004) argues that discovery learning is a way of teaching that involves students in the process of mental activity through exchange of opinions, with discussions, seminars, reading on their own and trying it themselves, so that children can learn on their own.

Suryosubroto stated that the discovery learning model is defined as a teaching procedure that emphasizes teaching, individuals, object manipulation and other experiments, before arriving at generalizations. Before students are aware of the understanding, the teacher does not explain in words. The use of discovery methods in the teaching and learning process allows students to discover for themselves the information that is traditionally used to be told or just told.

Meanwhile, Sani stated that the discovery learning model is finding a concept through a series of data or information obtained through observation or experiment. Discovery learning is a cognitive learning method that requires teachers to be more creative in creating situations that can make students learn to actively discover their own knowledge.

\section{Scientific approach}

The scientific approach is a scientific learning framework that is applied to the Curriculum. This learning process can be likened to a scientific process because it contains stages, especially in core activities. The scientific approach can also be referred to as a form of developing both religious and social attitudes, knowledge, and skills of students in applying subject matter. In this approach, students are no longer used as learning objects, but as learning subjects, teachers are only as facilitators and motivators. The teacher does not need to explain everything about what is in the material.

The scientific learning approach emphasizes the importance of collaboration and cooperation among students. The scientific approach is one of the scientific learning approaches. The application of the scientific approach aims at understanding students in knowing and understanding various materials using a scientific approach, that information can come from anywhere, anytime, not depending on direct information from the teacher (Setiawan \& Wilujeng, 2016; Wieman, 2007). Learning with a scientific approach is a learning process designed in such a way that students actively construct concepts, laws or principles through 
the stages of observing, formulating problems, proposing or formulating hypotheses, collecting data with various techniques, analyzing data, draw conclusions and communicate the concepts, laws or principles found (Reif, 1981; Yulianti, 2017; Reid, 2008).

Based on this description, it can be seen that the scientific approach is a student-centered approach so that students actively construct concepts, laws or principles through the stages of observing, formulating problems, proposing or formulating hypotheses, collecting data with various techniques, analyzing data, drawing conclusions and communicating the concept, law or principle found.

\section{Implementation Of Professional Activities}

\section{$1^{\text {st }}$ Meeting (Class Observation, Wednesday / 11 March 2020)}

Based on the results of observations made on March 11, 2020, it was found that teachers in the field of mathematics study used a direct learning model with the lecture and question and answer method. The learning process is only just listening to the teacher's explanation and some are busy with other matters, such as scribbling the back of their books and chatting with friends. This condition then encourages the author to conduct interviews with several students. The results of the interview showed that the student had difficulty learning mathematics because the subject was difficult and the use of a monotonous learning model made him feel bored and sleepy during the learning process, plus if the math class was scheduled during the day. However, there are also those who say that mathematics is not difficult but it depends on whether there is an interest in learning, if you have an intention it will be easy to understand the material and also depends on the way the teacher delivers the material and provides understanding to students.

In addition, at the first meeting with the observation activities of Mathematics subject teachers when teaching in class, namely by asking for direct guidance from the tutor teachers related to the learning framework used in this case the Learning Implementation Plan. The author will continue the learning process at the next meeting with the lesson plan reference by the homeroom teacher with a little updating using the Problem Basic Learning (PBL) model to increase the value of student learning outcomes.

\section{2nd Meeting (Learning Process, Thursday / 12 March 2020)}

The second is on Thursday, March 12, 2020. Lasts for 120 minutes (3 hours of lessons). Beam. The subject matter discussed at this meeting was "Knowing Cube and Block Nets". This meeting was attended by 25 students and it was recorded that 5 students did not attend. The learning process runs by referring to the learning tools according to the attached lesson plan.

The learning process takes place properly, using the Problem Basic Learning model, which is to divide students into groups then give students the opportunity to look for problems related to the subject matter then find solutions to be discussed together. Give students the opportunity to ask questions when some material has not been understood.

\section{3rd Meeting (Learning Process, Wednesday / 18 March 2020)}

The 3rd is on Wednesday, March 18 2020. It lasts for 120 minutes (3 lessons). The learning material is in accordance with the lesson plan as a reference and continues from the previous meeting material, namely the Cubes and Blocks. The subject matter discussed at this meeting is "Determining the Surface Area of Cubes and Blocks". This meeting was attended by 18 students and 12 students were not present. The learning process runs by referring to the learning tools according to the attached lesson plan. 
The learning process takes place properly, the discussion of the material to students is then followed by solving problems around the topics described, then continued with the distribution of exercise tasks to be completed by students in groups.

4th Meeting (Learning Process, Thursday 19 March 2020)

The 4th meeting is on Thursday, March 19 2020. It lasts for 120 minutes (3 lessons). The learning material is in accordance with the lesson plan as a reference and continues from the previous meeting material, namely in Prism and Limas chapters. The subject matter discussed at this meeting was "Determining the Surface Area of the Prism and Limas". This meeting was attended by 26 students and it was recorded that 4 students did not attend. The learning process runs by referring to the learning tools according to the attached lesson plan.

The learning process takes place properly, discussion of the material to students is then followed by group discussions by students to find problems in daily life associated with the material being discussed. Each group gives an example of the shape of the corner in a real environment then gives the other group the opportunity to respond. In this case, to train students to think critically and find solutions to problems

\section{Evaluation of 1st to 4th meetings}

\section{Evaluation of the 1st Meeting (Class Observation, Wednesday / 11 March 2020)}

In the 1st meeting, the activity carried out was the observation of the learning process carried out by mathematics teacher. At the meeting, the researcher managed to collect several results related to the learning methods that have been applied by the teacher, as well as how the learning process experienced by students. Problems found in class are then used as material for problem solving that will be carried out at the next meeting.

\section{Evaluation of the 2nd Meeting (Learning Process, Thursday / 12 March 2020)}

The second meeting was the learning process carried out by researchers through Problem Basic Learning. Learning takes place properly, but there are still some students who still do not focus on the material discussed in class. The obstacle, namely that the first day the researcher provided direct learning, it meant that students and researchers were still in the adaptation stage.

\section{Evaluation of the 3rd Meeting (Learning Process, Wednesday / 18 March 2020)}

The third meeting is the learning process carried out by researchers. The focus of students on researchers when explaining in the classroom has begun to build. The enthusiasm of students to ask opinions and questions was already visible. However, there are still some students who have not completed the individual assignments that have been given at the previous meeting, so that the researchers give additional time to work on assignments at school and there are still some students who have difficulty linking the discussion material with examples in everyday life.

\section{Evaluation of the 4th Meeting (Learning Process, Thursday 19 March 2020)}

The fourth meeting, namely the learning process carried out by researchers, was carried out using the method chosen by the researcher. Dividing students into groups reaped the results that were not optimal. Some students were found to be still having discussions outside of the material given, causing a slightly chaotic class scene. However, on the contrary, it gives flexibility to some students who take advantage of the group to really discuss and solve problems related to the material given. 


\section{Conclusion}

The conclusions that can be drawn after classroom action research with the application of the Discovery Learning model with a scientific approach for two cycles are as follows. The average score of students' mathematics learning outcomes in the first cycle was 68.44 from the ideal score that might be achieved by students, namely 100 with a standard deviation of 18.9. So, it can be said that most of the students completed the learning cycle I. The application of the Discovery Learning learning model with a scientific approach can improve the mathematics learning outcomes of students. The application of the Discovery Learning learning model with an effective scientific approach can increase the frequency of activeness and activities in the teaching and learning process according to the observations of student attitudes during the implementation of classroom action research in cycle I.

\section{References}

Barjesteh, H. (2019). Dynamicity of Transformative L2 Materials Preparation Model in EFL Classroom: Place of Critical Language Pedagogy in Teacher Education. Journal of Teaching Language Skills, 38(2), 47-79.

Brooks, S. L., \& Madden, R. G. (2011). Epistemology and ethics in relationship-centered legal education and practice. NYL Sch. L. Rev., 56, 331.

Gregory, E. M. (2006). Development and validation of an instrument of continuing professional development for inservice physical educators. The University of New Mexico.

Hirst, P. H. (2010). Knowledge and the curriculum (International Library of the Philosophy of Education Volume 12): A collection of philosophical papers. Routledge.

Klahr, D., \& Nigam, M. (2004). The equivalence of learning paths in early science instruction: Effects of direct instruction and discovery learning. Psychological science, 15(10), 661-667.

Mariyana, R. (2019). The Effectiveness of Guided-Discovery and Instructional Media on Early Mathematical Skills. Indonesian Journal of Early Childhood Education Studies, 8(1), 34-37.

Mercer, N., \& Fisher, E. (1992). How do teachers help children to learn? An analysis of teachers' interventions in computer-based activities. Learning and instruction, 2(4), 339-355.

Moore, M. (1986). Self-directed learning and distance education. International Journal of ELearning \& Distance Education/Revue internationale du e-learning et la formation à distance, 1(1), 7-24.

Reid, N. (2008). A scientific approach to the teaching of chemistry. What do we know about how students learn in the sciences, and how can we make our teaching match this to maximise performance?. Chemistry Education Research and Practice, 9(1), 51-59.

Reif, F. (1981). Teaching problem solving-A scientific approach. The Physics Teacher, 19(5), 310-316.

Setiawan, D., \& Wilujeng, I. (2016). The Development Of Scientific-Approach-Based Learning Instrumentsintegrated With Red Onion Farming Potency In Brebes Indonesia. Jurnal Pendidikan IPA Indonesia, 5(1), 22-30. 
Wells, G. (1993). Reevaluating the IRF sequence: A proposal for the articulation of theories of activity and discourse for the analysis of teaching and learning in the classroom. Linguistics and education, 5(1), 1-37.

Wieman, C. (2007). Why not try a scientific approach to science education?. Change: The Magazine of Higher Learning, 39(5), 9-15.

Yulianti, D. (2017, April). Problem-based learning model used to scientific approach based worksheet for physics to develop senior high school students characters. In Journal of Physics: Conference Series (Vol. 824, No. 1, p. 012009). 